\title{
Resveratrol Nanoemulsion; A Promising Inhibitor against Mitogen-Activated Protein Kinase - Dependent Inflammation and Ameliorates Nicotine induced-lung Toxicity in Rats
}

\author{
Fedaa Talat Mohamed', Ammar Yasser Abdelghfour', Bassant Argawy Morsy', Doaa Diaa Rizk', \\ Rania Mahmoud Elwany ${ }^{1}$, Samir Abdo Samir ${ }^{1}$, Ali Abdelaziz Ali ${ }^{2}$, Mohammed Abdalla Hussein ${ }^{3, *}$
}

\section{Fedaa Talat Mohamed', Ammar Yasser Abdelghfour ${ }^{1}$, Bassant Argawy Morsy ${ }^{1}$, Doaa Diaa Rizk ${ }^{1}$, Rania Mahmoud Elwany', Samir Abdo Samir ${ }^{1}$, Ali Abdelaziz Ali ${ }^{2}$, Mohammed Abdalla Hussein $^{3, *}$ \\ 'Department of Medical Laboratories, Faculty of Applied Medical Sciences, October 6 University, Sixth of October City, EGYPT. \\ ${ }^{2} V$ ice President of Post Graduate Studies, October 6 University, Sixth of October City, EGYPT. \\ ${ }^{3}$ Department of Biochemistry, Faculty of Applied Medical Sciences, October 6 University, Sixth of October City, EGYPT. \\ Correspondence}

Prof. Mohammed Abdalla Hussein

Professor of Biochemistry and Vice Dean for Post-graduate Studies and Scientific Research, Faculty of Applied Medical Sciences, October 6 University, EGYPT.

Phone no: +20 124832580

E-mail: prof.husseinma@o6u.edu.eg

History

- Submission Date: 07-03-2020;

- Review completed: 24-04-20;

- Accepted Date: 20-05-2020.

DOI : 10.5530/fra.2020.1.7

Article Available online

http://www.antiox.org

\section{Copyright}

(C) 2020 Phcog.Net. This is an openaccess article distributed under the terms of the Creative Commons Attribution 4.0 International license.

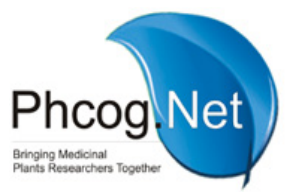

\begin{abstract}
Background: Nicotine, a major component of cigarette smoke, plays an important role in the development of cardiovascular disease and lung cancer in smokers. The aim of the present article was to investigate protective activity of resveratrol nanoemulsion (RENE) against lung toxicity induced by nicotine in adult rats as compared to basic resveratrol. Materials and Methods: RENE was prepared using bovine serum albumin method, then characterized for their particle size and zeta potential. Furthermore, Adult albino rats weighing around $150 \pm 10 \mathrm{~g}$ were used for the evaluation of lung protective activity of RENE (50 mg/k.b.w.) against nicotine-induced lung toxicity in rats. Results: The mean particle size of RENE was $49.5 \pm$ $0.05 \mathrm{~nm}$ and zeta potential of +15.75 with the observed shapes of nanoparticle was spherical. The daily oral administration of the RENE at a concentration of $39.75 \mathrm{mg} / \mathrm{kg}$ body weight for 30 days to rats treated with nicotine $(2.5 \mathrm{mg} / \mathrm{kg}$.b.w.) resulted in a significant improve plasma cholesterol, triglyceride, HDL-cholesterol, LDL-cholesterol as well as serum tumor necrosis factor alpha (TNF- $\alpha$ ), interleukin 6 (IL-6) and growth factor (TGF)- $\beta 1$ in nicotine treated groups rats. On the other hand, oral administration of RENE elevated the activity of superoxide dismutase (SOD), glutathione peroxidase (GPX) and total protein kinase-1 (Akt-1) as well as reduced the level malondialdehyde (MDA) in lung rats treated with nicotine. In addition, RENE reduced the expression of lung inducible nitric oxide synthase (iNOS) and mitogen-activated protein kinase (p38-MAPK) levels as compared to nicotine treated control group. Also, RENE and resveratrol almost normalized these effects in the histoarchitecture of the lung. Conclusion: The obtained biochemical, molecular biology and histological results of our study proved the lung protective activity of RENE against nicotine induced lung toxicity in rats.
\end{abstract}

Key words: Resveratrol nanoemulsion, Nicotine, Lung, Nanoparticles and p38-MAPK.

\section{INTRODUCTION}

Smoking is a major risk factor for cardiovascular morbidity and mortality. ${ }^{1,2} 25 \%$ of middle-aged cardiovascular deaths are attributable to smoking. ${ }^{3}$

Nicotine is classed as an alkaloid (like morphine and cocaine) and meets the criteria of a highly addictive drug. 1.2-2.9 mg of nicotine, in each cigarette. ${ }^{4}$ As an addictive drug, nicotine has 2 very potent effects: it is a stimulant and it is also a depressant. ${ }^{5,6}$ Also, nicotine increases serum levels of HDL-C and LDLC. ${ }^{78}$ It has been recognized to result in oxidative stress by inducing the generation of reactive oxygen species (ROS). ${ }^{9}$ These ROS in turn are capable of initiating and promoting oxidative damage in the form of lipid peroxidation. ${ }^{10}$ Many plant products have been shown to have significant antioxidant activity, ${ }^{11}$ which may be an important property of medicinal plants associated with the treatment of several illfated diseases. ${ }^{12}$

Resveratrol is found in more than 70 species of plants, particularly in grapes, blueberries and peanuts ${ }^{13}$ as well as red wine. ${ }^{14}$ Not surprisingly, a phenolic compound such as resveratrol, an excellent scavenger of reactive oxygen species ${ }^{15}$ and anticholestatic activity. ${ }^{11}$ It is also speculated that resveratrol could be effective in controlling of hyperglycemia and dyslipidemia in diabetes. ${ }^{16}$

Nanotechnology is at the forefront of cancer research. This technology allows scientists to target cancer cells. ${ }^{17}$ Nanoparticles can decrease side effects in patients by directly targeting the area of disease and eliminating the need to circulate through the body. ${ }^{18,19}$ When encapsulating drugs into nanoparticles,

Cite this article: Mohamed FT, Abdelghfour AY, Morsy BA, Rizk DD, Elwany RM, Samir SA, Ali AA, Hussein MA. Resveratrol Nanoemulsion; A Promising Inhibitor against Mitogen-Activated Protein Kinase - Dependent Inflammation and Ameliorates Nicotine induced-lung Toxicity in Rats. Free Radicals and Antioxidants. 2020;10(1):35-41. 
researchers observed improved drug solubility, controlled drug release, enhanced bioavailability, increased stability and improved long-term storage (versus non-encapsulated drugs). ${ }^{20}$ These attributes are promising and could be the traits needed to combat disease. ${ }^{21}$ As an extension of my interested research program to evaluate the medicinal importance of resveratrol (11, 15 and 21) we report herein, a facile route to evaluate the therapeutic potential of resveratrol nanoemulsion on rat lung toxicity induced by nicotine.

\section{MATERIALS AND METHODS}

\section{Materials}

Resveratrol (97\%.5\%), Trypan Blue, Bovine serum albumin, Glutaraldehyde 50\%, nicotine (98\%), RPMI1640 (Roswell park memorial institute) medium with L-glutamine (Cambrex, Belgium) were purchased from Sigma Chemical Co. (St. Louis, MO, USA). All other chemicals used in this study were of the analytical grade.

\section{Resveratrol nano-emulsion preparation}

Resveratrol nano-emulsion was prepared according the method of Hussein et al. ${ }^{21} 100 \mathrm{mg}$ bovine serum albumin (BSA) is dissolved in $12 \mathrm{ml}$ distilled water; dissolve the resveratrol $24 \mathrm{mg}$ in $24 \mathrm{ml}$ ethanol then add drop wise the ethanolic solution on the BSA solution under stirring $(500 \mathrm{rpm})$; then add $3 \mathrm{ml} \mathrm{11 \%}$ glutaraldehyde and leave on stirring overnight.

\section{Resveratrol nano-emulsion characterization}

The crystalline nature and grain size of RENE was carried out by X- ray diffraction pattern at $25-28^{\circ} \mathrm{C}$ with a D8 Advance $\mathrm{X}$-ray diffractometer (Bruker - Germany) with a nickel (Ni) filtered using $\mathrm{CuKa}(\lambda=1.54184$ $\mathrm{A} 0$ ) radiations as an X-ray source. Infrared spectrum (IR) of sample is registered using Nicolet 6700 . The thermal analysis was measured using Thermo gravimetric analysis. Morphology and size of RENE were examined by Scanning Electron Microscope and Field Emission Transmission Electron Microscopy at an accelerating voltage of $15 \mathrm{Kv}$ and $200 \mathrm{Kv}$.

\section{Animals}

Male albino rats weighing around $150 \pm 10 \mathrm{~g}$ were obtained from animal house of Faculty of Veterinary Medicine, Cairo University, Giza, Egypt. They were housed in plastic cages with stainless steel covers at the National Cancer Institute Animal House. The animals were maintained at a temperature of $22 \pm 1^{\circ} \mathrm{C}$ and a humidity of $55-60 \%$ in a light-controlled room. The animals were kept for 1 week to acclimatize and provided with standard diet and water ad libitum.

\section{Experimental setup}

This experiment was carried out to examine the protective effect of RENE against nicotine-induced lung toxicity. This experiment was conducted in accordance with guidelines established by the Animal Care and Use Committee of October $6^{\text {th }}$ University. Adult albino rats were divided into six groups with six animals in each. The treatment groups are described in Table (1).

\section{Biochemical assays}

Blood samples were withdrawn from the retro-orbital vein of each fasted animal. Blood was collected using sodium fluoride as anticoagulant, centrifuged and plasma was used freshly for estimation of triglyceride, total cholesterol and HDL-C were determined. ${ }^{23-25}$ Plasma LDL-cholesterol level was calculated from Falholt et al. ${ }^{26}$ formula.

Plasma tumor necrosis factor-alpha (TNF- $\alpha$ ), interleukin 6 (IL-6) and total Akt-1 levels were performed using a series of ELISA kits. The lung
Table 1: Description of treatment groups.

\begin{tabular}{|c|c|c|}
\hline Group & Group name & Treatment description \\
\hline I & Normal control A & $3 \mathrm{~mL}$ of distilled water, orally for 30 days \\
\hline II & Normal control B & $3 \mathrm{~mL}$ of tween $80,1 \%$, orally for 30 days \\
\hline III & Nicotine & $\begin{array}{l}\text { Subcutaneous injection of } 2.5 \mathrm{mg} / \mathrm{kg} \text { b.w. } \\
\text { nicotine }{ }^{22} \text { in tween } 80,1 \% \text {, for } 30 \text { days }\end{array}$ \\
\hline IV & RENE & $\begin{array}{l}\text { Oral suspension of } 39.75 \mathrm{mg} / \mathrm{kg} \text { b.w. in } \\
\text { tween } 80,1 \%{ }^{21}\end{array}$ \\
\hline $\mathrm{V}$ & RENE + Nicotine & $\begin{array}{c}\text { Oral suspension of } 39.75 \mathrm{mg} / \mathrm{kg} \text { b.w. RENE } \\
\text { in tween } 80,1 \% \text {. subcutaneous injection } \\
\text { of } 2.5 \mathrm{mg} / \mathrm{kg} \text { b.w. nicotine in tween } 80,1 \% \text {, } \\
\text { for } 30 \text { days in a single daily dose }\end{array}$ \\
\hline VI & $\begin{array}{l}\text { Basic resveratrol + } \\
\quad \text { Nicotine }\end{array}$ & $\begin{array}{l}\text { Oral suspension of } 50 \mathrm{mg} / \mathrm{kg} \text { b.w. basic } \\
\text { resveratrol in tween } 80,1 \% .(11)+ \\
\text { subcutaneous injection of } 2.5 \mathrm{mg} / \mathrm{kg} \text { b.w. } \\
\text { nicotine in tween } 80,1 \% \text {, for } 30 \text { days in a } \\
\text { single daily dose }\end{array}$ \\
\hline
\end{tabular}

superoxide dismutase assay kit utilizes a tetrazolium salt. ${ }^{27}$ The glutathione peroxidase assay kit measures GPx activity indirectly by a coupled reaction with GR (28). Also, A thiobarbituric-acid-reactive substance assay was used to measure the lung lipid peroxidation products, malondialdehyde (MDA) equivalents. ${ }^{29}$

\section{Western blot}

Lung samples of three rats from each group were taken 3 min after the last administration. The samples were added with the lysis buffer on the ice for cracking for $1 \mathrm{hr}$ and then centrifuged at $16,009.2 \times g$ to obtain the supernatant. The tissue protein concentration in the supernatant was determined by bicinchoninic acid (BCA) method and 10\% SDSPAGE gel electrophoresis was used to isolate $\beta$-actin, iNOS and p38 MAPK. The proteins were transferred onto PVDF membrane for $2 \mathrm{hr}$ and the membrane was rinsed with Tris buffer saline Tween (TBST) for $5 \mathrm{~min}$ and then blocked with the blocking buffer for $1 \mathrm{hr}$. After the incubation at room temperature, the blocking buffer was discarded. The first antibodies of iNOS (1:1000), $\beta$-actin (1:1000) and p38 MAPK (1:1000) Santa Cruz Biotechnology, Inc, Calif, USA) were added onto the membrane, respectively, which was incubated at $4^{\circ} \mathrm{C}$ overnight and then washed with TBST five times, 5 min each time; the second antibody $(1: 2,000)$ were added onto the membrane, which was incubated for $2 \mathrm{hr}$ and then washed five times with TBST, 5 min each time and finally, ECL color solution was added onto the membrane for its development.

\section{Histological assessment}

The lung was sliced and pieces were fixed in $10 \%$ buffered formaldehyde solution for histological study. Sections of $5 \mathrm{ml}$ in thickness were prepared and then stained with hematoxylin and eosin for light microscopy analyses according to the method of Bancroft and Steven. ${ }^{30}$

\section{Statistical analysis}

The results were expressed as mean \pm SD for eight separate determinations. All the data were statistically evaluated with SPSS/18 Software. $P$ values of $<0.01$ were considered to indicate statistical significance.

\section{RESULTS}

IR spectrum infrared spectrogram of the basic resveratrol and resveratrol nanoemulsion shows a phenol hydroxyl groups absorption peak at 3252 and $3436 \mathrm{~cm}^{-1}$, respectively, as well as benzene ring absorption peaks at 2827, 2920 exists. 
LST as well as TEM analysis shows that resveratrol nanoemulsion had size of around $49.5 \pm 0.05 \mathrm{~nm}$ with negative zeta potential of +15.75 .

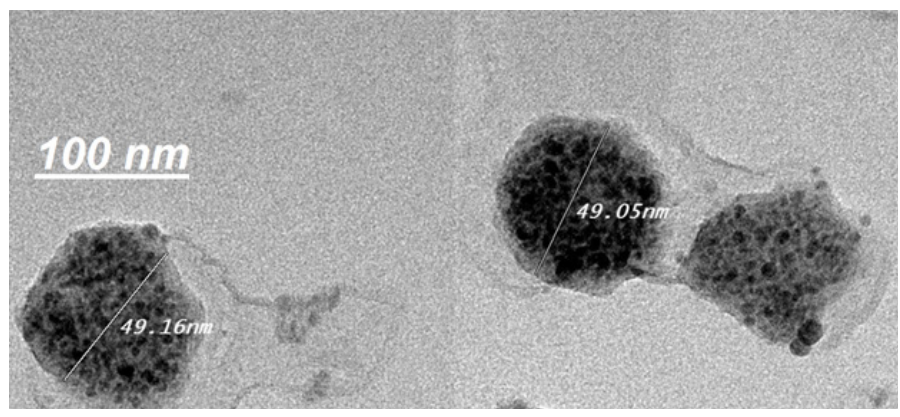

Tables 2 show plasma lipid profile levels. Nicotine administration led to significant increase of biochemical marker levels for cholesterol, triglycerides and LDL-cholesterol while significantly decreasing HDLcholesterol, respectively, as compared with the normal control group $(P<$ 0.05 ), indicating acute lung injury. Treatment of animals with RENE and basic resveratrol 39.75 and $50 \mathrm{mg} / \mathrm{kg}$.b.w., significantly reduced the level of cholesterol, triglycerides and LDL-cholesterol as well as significantly increased HDL- cholesterol, respectively, $(P<0.05)$, as compared with the nicotine treated group.

Table 3 revealed a significant elevation in plasma TNF- $\alpha$ and IL- 6 as well as significant decrease in TGF- $\beta 1$ levels $(p<0.05)$ in the second group which represents nicotine $(2.5 \mathrm{mg} / \mathrm{kg})$ treated the group of rats compared with control group. The administration of RENE and basic resveratrol showed significantly decreased in TNF- $\alpha$ and IL- 6 as well as significant

Table 2: Effect of resveratrol nanoemulsion (RENE) and basic resveratrol on plasma lipid profile in rats treated with nicotine.

\begin{tabular}{|c|c|c|c|c|c|}
\hline $\begin{array}{l}\text { 气ั } \\
\frac{0}{3} \\
\text { ㄴ }\end{array}$ & 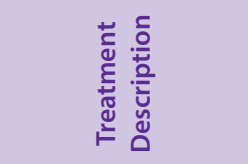 & 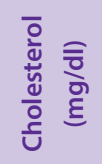 & 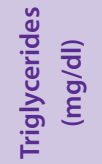 & 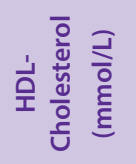 & 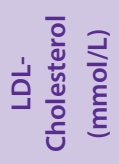 \\
\hline \multirow[t]{2}{*}{ I } & Normal control A & 92.6 & 65.37 & 33.60 & 45.93 \\
\hline & $\begin{array}{l}3 \mathrm{~mL} \text { of distilled } \\
\text { water, orally }\end{array}$ & $\pm 3.17^{\mathrm{a}}$ & $\pm 2.97^{\mathrm{a}}$ & $\pm 2.57^{\mathrm{a}}$ & $\pm 4.86^{\mathrm{a}}$ \\
\hline \multirow[t]{2}{*}{ II } & Normal control B & 93.44 & 60.40 & 31.88 & 49.48 \\
\hline & $\begin{array}{c}3 \mathrm{~mL} \text { of tween } 80, \\
1 \% \text {, orally }\end{array}$ & $\pm 5.30^{\mathrm{a}}$ & $\pm 3.46^{\mathrm{a}}$ & $\pm 3.09^{\mathrm{a}}$ & $\pm 5.03^{\mathrm{a}}$ \\
\hline \multirow[t]{2}{*}{ III } & RENE & 90.54 & 63.08 & 30.65 & 47.27 \\
\hline & $\begin{array}{l}39.75 \mathrm{mg} / \mathrm{kg} \text { b.w. in } \\
\text { tween } 80,1 \% \text {, orally }\end{array}$ & $\pm 3.21^{\mathrm{b}}$ & $\pm 6.00^{\mathrm{a}}$ & $\pm 4.00^{\mathrm{a}}$ & $\pm 4.21^{\mathrm{a}}$ \\
\hline \multirow[t]{2}{*}{ IV } & Nicotine & 136.76 & 97.50 & 19.80 & 97.46 \\
\hline & $\begin{array}{l}2.5 \mathrm{mg} / \mathrm{kg} \text { b.w. } \\
\text { in tween } 80,1 \% \text {, } \\
\text { subcutaneous } \\
\text { injection }\end{array}$ & $\pm 4.11^{\mathrm{e}}$ & $\pm 3.89^{\mathrm{d}}$ & $\pm 2.43^{\mathrm{a}}$ & $\pm 4.62^{\mathrm{d}}$ \\
\hline $\mathrm{V}$ & $\begin{array}{c}\text { RENE (39.75 mg/kg } \\
\text { b.w.) + (Nicotine } 2.5 \\
\text { mg/kg b.w.) }\end{array}$ & $\begin{array}{r}100.68 \\
\pm 6.17^{c}\end{array}$ & $\begin{array}{c}68.72 \\
\pm 7.25^{\mathrm{b}}\end{array}$ & $\begin{array}{c}35.11 \\
\pm 3.90^{\mathrm{a}}\end{array}$ & $\begin{array}{c}51.83 \\
\pm 3.90^{\mathrm{b}}\end{array}$ \\
\hline VI & $\begin{array}{c}\text { Basic resveratrol } \\
(50 \mathrm{mg} / \mathrm{kg} \text { b.w. })+ \\
\text { Nicotine }(2.5 \mathrm{mg} / \\
\text { kg b.w. })\end{array}$ & $\begin{array}{l}110.37 \\
\pm 5.21^{\mathrm{d}}\end{array}$ & $\begin{array}{r}85.20 \\
\pm 5.09^{c}\end{array}$ & $\begin{array}{c}26.49 \\
\pm 2.80^{\mathrm{b}}\end{array}$ & $\begin{array}{c}66.84 \\
\pm 5.35^{\mathrm{c}}\end{array}$ \\
\hline
\end{tabular}

Data shown are mean \pm standard deviation of number of observations within each treatment. Data followed by the same letter are not significantly different at $P \leq 0.05$.
Table 3: Effect of resveratrol nanoemulsion (RENE) and basic resveratrol on levels of serum tumor necrosis factor alpha (TNF- $\alpha$ ), interleukin 6 (IL6) and growth factor (TGF)- $\beta 1$ in rats treated with nicotine.

\begin{tabular}{|c|c|c|c|c|}
\hline Groups & $\begin{array}{l}\text { Treatment } \\
\text { Description }\end{array}$ & $\begin{array}{l}\text { TNF-a } \\
(\mathrm{pg} / \mathrm{ml})\end{array}$ & $\begin{array}{c}\text { IL-10 } \\
\text { (pg/mL) }\end{array}$ & $\begin{array}{l}\text { TGF- } \beta 1 \\
(\mathrm{pg} / \mathrm{mL})\end{array}$ \\
\hline \multirow[t]{2}{*}{ I } & Normal control A & 15.64 & 12.65 & 63.54 \\
\hline & $\begin{array}{c}3 \mathrm{~mL} \text { of distilled water, } \\
\text { orally }\end{array}$ & $\pm 1.65^{\mathrm{a}}$ & $\pm 1.26^{\mathrm{a}}$ & $\pm 4.00^{\mathrm{a}}$ \\
\hline \multirow[t]{2}{*}{ II } & Normal control B & 14.88 & 13.61 & 62.10 \\
\hline & $\begin{array}{c}3 \mathrm{~mL} \text { of tween } 80,1 \% \text {, } \\
\text { orally }\end{array}$ & $\pm 2.03^{\mathrm{a}}$ & $\pm 1.54^{\mathrm{a}}$ & $\pm 4.35^{\mathrm{a}}$ \\
\hline \multirow[t]{2}{*}{ III } & RENE & 90.54 & 63.08 & 30.65 \\
\hline & $\begin{array}{l}39.75 \mathrm{mg} / \mathrm{kg} \text { b.w. in } \\
\text { tween } 80,1 \% \text {, orally }\end{array}$ & $\pm 3.21^{\mathrm{b}}$ & $\pm 6.00^{\mathrm{a}}$ & $\pm 4.00^{\mathrm{a}}$ \\
\hline \multirow[t]{2}{*}{ IV } & Nicotine & 58.70 & 26.54 & 197.60 \\
\hline & $\begin{array}{l}2.5 \mathrm{mg} / \mathrm{kg} \text { b.w. in tween } \\
80,1 \% \text {, subcutaneous } \\
\text { injection }\end{array}$ & $\pm 3.20^{\mathrm{d}}$ & $\pm 2.00^{c}$ & $\pm 11.25^{\mathrm{d}}$ \\
\hline \multirow[t]{2}{*}{ V } & RENE $(39.75 \mathrm{mg} / \mathrm{kg}$ & 19.65 & 16.90 & 73.25 \\
\hline & $\begin{array}{c}\text { b.w. })+(\text { Nicotine } 2.5 \\
\mathrm{mg} / \mathrm{kg} \text { b.w. })\end{array}$ & $\pm 2.05^{\mathrm{b}}$ & $\pm 1.56^{\mathrm{b}}$ & $\pm 5.42^{\mathrm{b}}$ \\
\hline \multirow[t]{2}{*}{ VI } & Basic resveratrol (50 & 29.00 & 17.80 & 82.30 \\
\hline & $\begin{array}{c}\mathrm{mg} / \mathrm{kg} \text { b.w. })+ \text { Nicotine } \\
(2.5 \mathrm{mg} / \mathrm{kg} \text { b.w. })\end{array}$ & $\pm 2.17^{c}$ & $\pm 2.09^{\mathrm{b}}$ & $\pm 4.70^{\mathrm{c}}$ \\
\hline
\end{tabular}

Data shown are mean \pm standard deviation of number of observations within each treatment.

Data followed by the same letter are not significantly different at $P \leq 0.05$.

increase in TGF- $\beta 1$ levels relative to nicotine treated the group of rats after 30 days $(p<0.05)$.

Table 4 show a significantly $(P<0.05)$ decreased activities of lung antioxidant enzymes SOD, GPx and total Akt-1 while significantly increasing lung MDA, were observed in the nicotine-treated rats as compared with the normal control group $(P<0.05)$, indicating acute lung damage. RENE and basic resveratrol treatment significantly $(P<0.05)$ enhanced the lung enzymes activities SOD, GPx and total Akt-1 in rats and decrease MDA level, as compared to the nicotine-treated group.

Figure 1 displayed that nicotine $(2,5 \mathrm{mg} / \mathrm{kg})$ promoted the iNOS protein expression in nicotine- treated the group of rats compared with control group. Administration of RENE and basic resveratrol treatment led to a statistically significant decrease of iNOS protein expression relative to nicotine treated group of rats $(p<0.05)$. Agarose gel electrophoresis images of iNOS and $\beta$-actin by RT-PCR support the present results Figure 2.

RT-PCR results (Figure 3 ) showed that significant increase in the expression levels of p38 MAPK in group of treated rats with nicotine $(2.5 \mathrm{mg} / \mathrm{kg})$ when compared with normal control group of rats. Also, Administration of RENE and basic resveratrol treatment led to a statistically significant decrease of $\mathrm{p} 38$ MAPK protein expression relative to nicotine treated rats $(p<0.05)$. Agarose gel electrophoresis images of p38 MAPK and $\beta$-actin by RT-PCR support the present results Figure 2.

\section{Histopathology examination}

Histopathological examination of lung sections of the normal groups (I and II) as well as RENE treated group (III) demonstrated normal morphological features of lung parenchyma with apparent intact respiratory airways epithelium as well as alveolar walls (arrows) with intact vasculatures. Figure 4 (I-III) 
Table 4: Effect of resveratrol nanoemulsion (RENE) and basic resveratrol on activity of superoxide dismutase (SOD), glutathione peroxidase (GPx) and total protein kinase-1 (Akt-1) as well as malondialdehyde (MDA) level in lung rats treated with nicotine.

$\left.\begin{array}{cccccc}\text { Groups } & \begin{array}{c}\text { Treatment } \\ \text { Description }\end{array} & \begin{array}{c}\text { SOD } \\ \text { (U/mg } \\ \text { protein) }\end{array} & \begin{array}{c}\text { GPx } \\ \text { (U/mg } \\ \text { protein) }\end{array} & \begin{array}{c}\text { Total } \\ \text { Akt-1 } \\ \text { (ng/mg } \\ \text { protein) }\end{array} & \begin{array}{c}\text { MDA } \\ \text { (nmol/ } \\ \text { mg }\end{array} \\ \text { protein) }\end{array}\right)$

Values are given as mean \pm SD for groups of six animals each. Data shown are mean \pm standard deviation of number of observations within each treatment. Data followed by the same letter are not significantly different at $\mathrm{P} \leq 0.05$. SOD: one unit of activity was taken as the enzyme reaction, which gave $50 \%$ inhibition of NBT reduction in $1 \mathrm{~min} / \mathrm{mg}$ protein; GPx: $\mu \mathrm{g}$ of GSH consumed/min mg protein;

On the other hand, in the lung of nicotine-treated control group (IV), histological examination showed marked diffuse hemorrhagic pneumonia with extravasation of blood into alveolar lumen and intrabronchiolar lumen (stars) accompanied with sever thickening of interalveiolar walls and peribronchiolar tissue with many inflammatory cells infiltrates (arrow). Figure 4 (IV)

Histopathological examination also showed good recovery of nicotineinduced lung toxicity $(\mathrm{V})$ by RNE as compared with the nicotine-treated group and showed almost the same records as Groups I- III. Figure 4 (V) Group (VI) all samples of nicotine treated rats recovery by treatment with basic resveratrol and showed almost intact morphological features of pulmonary tissue with minimal records of inflammatory cells infiltrates. Figure 4 (VI)

\section{DISCUSSION}

Smoking ranks among the top causes of cardiovascular disease, including coronary heart disease, ischemic stroke, peripheral artery disease and abdominal aortic aneurysm. ${ }^{4}$ It is also associated with an increased risk of certain types of cancer and is a major cause of chronic obstructive pulmonary disease. ${ }^{31}$

In the present study, the levels of total cholesterol and triglycerides and low-density lipoprotein (LDL) by rats during experimental period were significantly increased in nicotine-treated rats when compared with

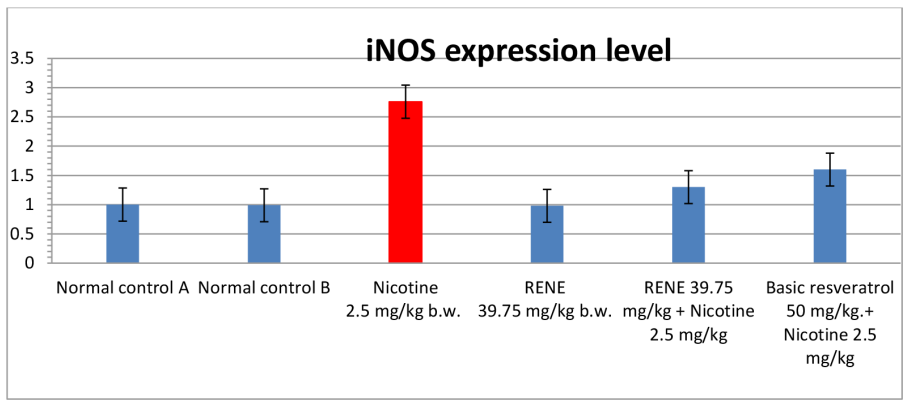

Figure 1: Effect of resveratrol nanoemulsion (RENE) and basic resveratrol on levels of lung inducible nitric oxide synthase (iNOS) in rats. Representative bar diagram of three independent experiments are presented.

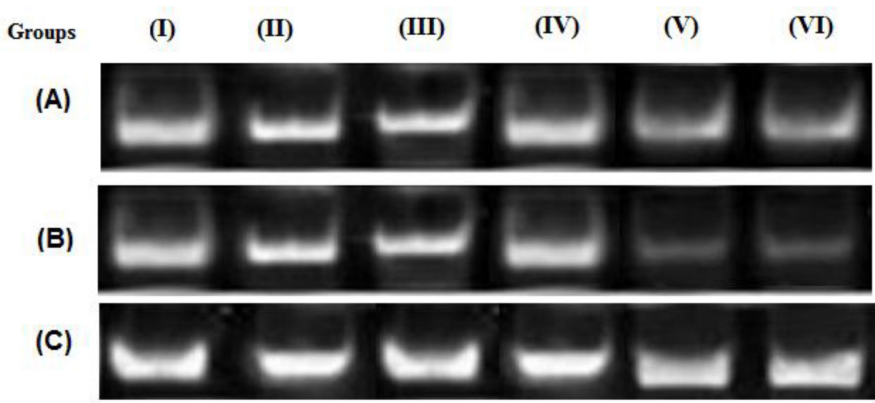

Figure 2: An agarose gel electrophoresis shows PCR products of lung inducible nitric oxide synthase (iNOS) (A) and p38 mitogen-activated protein kinase (p38-MAPK) (B) and beta actin (C) in different studied groups.

p38 MAPK x (1000)

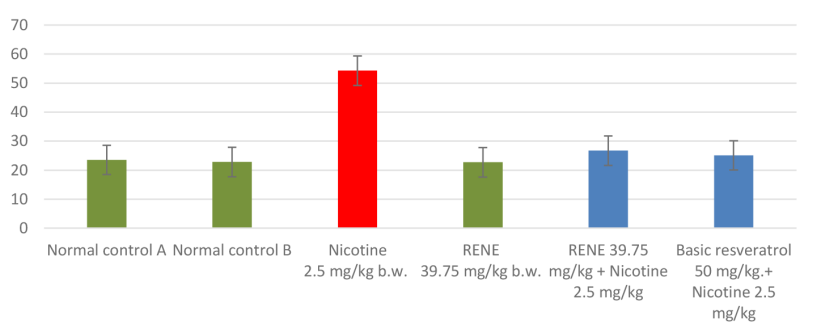

Figure 3: Effect of resveratrol nanoemulsion (RENE) and basic resveratrol on lung phosphospecific p38 mitogen-activated protein kinase (p38-MAPK) in rats. Representative bar diagram of three independent experiments are presented.
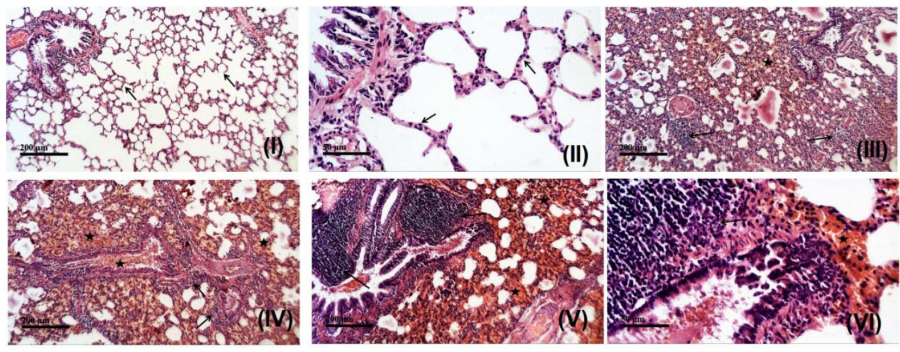

Figure 4 (I-VI): Histological examination of different pulmonary tissue samples. 
normal control rats. On the other hand, nicotine lowers plasma levels of high-density lipoprotein (HDL), a powerful protective factor against the development of atherosclerosis. ${ }^{32}$

Also, oral administration of RENE and basic resveratrol at 39.75 and $50 \mathrm{mg} / \mathrm{kg}$ b.w., respectively, showed significant protection against nicotine induced increase in plasma cholesterol, triglycerides and LDL.

The deposited cholesterol esters in the tissue need hydrolysis to release free cholesterol. One of the hydrolysis factors is HDL, since HDLcholesterol level was found to be decreased in atherogenic diet fed rats, ${ }^{33}$ the insufficient HDL level may lead to free cholesterol in plasma, enhancing the pathogenesis. Our results showed that resveratrol nanoemulsion (RENE) and basic resveratrol enhanced HDL in treated rats. The most obvious effect of resveratrol on lipid profile was its action on in vivo LDL. Resveratrol nanoemulsion (RENE) and basic resveratrol reduced the LDL in nicotine treated rats. LDL promotes atherosclerosis both by providing lipids signals that initially activate macrophages and by stimulating foam cell formation. ${ }^{33}$

The present results show that RENE could inhibit serum TNF- $\alpha$, IL- 6 and TGF- $\beta 1$ levels in the nicotine-treated group. Free radicals are involved in the regulation of cell proliferation and death, as well as gene expression such as TNF- $\alpha$, IL-6, TGF- $\beta 1$ and MDA. ${ }^{11}$ Evidence indicates that free radicals, oxidative stress and lipid peroxidation are present in organs damage. ${ }^{34}$ It has been shown that in chronic lung toxicity, the increased lung concentration of as TNF- $\alpha$, IL-6, TGF- $\beta 1$ and MDA and decrease activity of SOD, GPx and Akt-1 induces mitochondrial toxicity and free-radical generation. ${ }^{35}$ TNF- $\alpha$, TGF- $\beta 1$ and interleukin- 6 are the most extensively studied mitogenic and fibrogenic factors. RES is also able to inhibit proinflammatory cytokine expression. ${ }^{36}$ Taken together, these results indicate that the antifibrotic effect of RENE is associated with the blockade of mitogenic and/or fibrogenic signaling. TNF- $\alpha$ was reported to induce NO formation. ${ }^{37}$ RENE and basic resveratrol are a potent reactive oxygen species (ROS) scavenger ${ }^{38}$ and normalized the oxidative stress biomarkers SOD, GPx, Akt-1 and MDA, resulting in reduced oxidative stress, which contributes to suppression of lung inflammation by nicotine. In the present study, the significant decrease in lung SOD, GPx and Akt-1 activity were detected after nicotine administration.

In the present study, lung toxicity by nicotine, iNOS begins to express and generate a large number of $\mathrm{NO}$ and endogenous $\mathrm{NO}$ is massively released into regional damaged lung tissue, which directly react or interact with other factors, indirectly involved in scar formation and evolution process by adjusting firoblasts, endothelial cells and other functions. ${ }^{39}$

There are more major findings in the resveratrol study. First, the present results shown that TNF- $\alpha$-induced increased monocyte adhesiveness to Human Coronary Artery Endothelial Cells (HCAECs) is NF- $\mathrm{kB}$ dependent and it can be inhibited by resveratrol. ${ }^{40}$ IL-10 and iNOS protein expression also elicited endothelial activation and this effect also could be attenuated by resveratrol. It is significant that resveratrol also attenuated $\mathrm{H}_{2} \mathrm{O}_{2}$-induced monocyte adhesion to HCAECs in a similar concentration range. The second important finding is that TNF- $a$ -induced NF- $\kappa B$ activation in HCAECs is inhibited by treatment with resveratrol. ${ }^{41}$ The present study was in confirmed with other studies ${ }^{42}$ suggested that resveratrol was effective against iNOS protein expression, IL-10 and TGF- $\beta 1$-induced NF- $\mathrm{KB}$ activation in intact blood vessels.

In lung cells, TNF- $\alpha$, IL-6, TGF- $\beta 1$ can induce P38MAPK activation and increase its activity, thereby inducing cardiac endothelial cell death and stimulating neutrophil function, leading to the increase of TNF- $\alpha$, IL-6, TGF- $\beta 1-\alpha$ and the accumulation of neutrophils in lung tissue and damage it's cells. ${ }^{43}$ In our study, we found that baicalin significantly downregulated P38MAPK protein expression in rat with nicotine induced lung toxicity group. Usta et al. concluded that treatment with resveratrol suppresses migration, invasion and metastasis through p38MAPK signaling pathway in human cardiac tissue. ${ }^{43}$

Indeed, there was remarkable reduction in fibrosis extent and a decrease of stellate infiltration in rats treated with RENE groups compared to the control nicotine treated group. Histological studies confirmed the lung protective effect of RES. Since the proliferation of lung is an early event in toxicity-related changes, the attenuation of lung injury and fibrosis in rats by RENE might be associated with alleviation of inflammatory reaction. Prophylactic effect of RENE against nicotine-induced lung toxicity has not been reported earlier to my knowledge and this study is perhaps the first observation of its kind.

\section{CONCLUSION}

The present study showed that RENE has powerful lung protective activity against nicotine-induced lung toxicity, via normalize the levels oxidative stress biomarkers and gene expression of inflammatory mediators.

\section{Ethics approval and consent to participate}

Ethical approval for the data collection was granted by the Research Ethics Committee at the Faculty of Applied Medical Sciences, October 6 University, Egypt (No. 20191102). No Humans were used studies that are base of this research, in-vivo study using rats only.

\section{CONFLICT OF INTEREST}

The authors declare no conflict of interest, financial or otherwise.

\section{ABBREVIATIONS}

RENE: Resveratrol nanoemulsion; HDL-C: HDL-cholesterol; LDL-C: LDL-cholesterol; TNF- $\alpha$ : Tumor necrosis factor alpha; IL-6: interleukin 6; TGF- $\beta 1$ : Growth factor, SOD: Superoxide dismutase; GPx: Glutathione peroxidase; Akt-1: total protein kinase-1; iNOS: Inducible nitric oxide synthase; p38-MAPK: mitogen-activated protein kinase.

\section{REFERENCES}

1. World Health Organization. Report on the Global Tobacco Epidemic. Geneva 2008. Available at: http://www.who.int/tobacco/mpower/mpow erreport full_2008.pdf (2013).

2. U.S. Department of Health and Human Services. National Center for Chronic Disease Prevention and Health Promotion. Office on Smoking and Health. The Health Consequences of Smoking: A Report of the Surgeon General. Atlanta. 2004. Available at: http://www.cdc.gov/tobacco/data_statistics/s gr/2004/ complete_report/index.htm (2013)

3. World Health Organization. World Health Report on Reducing Risks and Promoting Healthy Life. Geneva. 2002. Available at: http://www.who.int/ whr/2002/en/whr02_en.

4. Lande RG. Nicotine Addiction. Pathophysiology. Walter Reed Army Medical Center. Department of Psychiatry. Medscape Updated. 2012. available at: http:// emedicine.medscape.com/article/2875 55-overview\#a0104 (2013).

5. Robertson D, Tseng CJ, Appalsamy M. Smoking and mechanisms of cardiovascular control. Am Heart J. 1988;115(1):258-62.

6. Benowitz NL, Gourlay SG. Cardiovascular Toxicity of Nicotine: Implications for Nicotine Replacement Therapy. J Am Coll Cardiol. 1997;29(7):1422-31.

7. Lagrue G, Grimaldi B, Martin C, Demania C, Jacotot B. Nicotine Gum and the Lipid Profile. Pathol Biol. 1989;37(8):937-41.

8. Burch EA, JrKadowitz PJ, Kother CS, JrNamara DBM. The Effect of Alcoholism and Smoking on Platelet Eicosanoid Production in vitro, Prostaglandins. Leukotrienes Essent. Fatty Acids. 1991;42(1):39-44.

9. Sudheer AR, Muthukumaran S, Devipriya N, Menon VP. Ellagic acid, a natural polyphenol protects rat peripheral blood lymphocytes against nicotine-induced cellular and DNA damage in vitro: with the comparison of $\mathrm{N}$-acetylcysteine. Toxicology. 2007;230(1):11-21.

10. Kovacic P, Cooksy A. Iminium metabolite mechanism for nicotine toxicity and addiction: Oxidative stress and electron transfer. Med Hypotheses. 2005;64(1):104-111.

11. Hussien MA. Prophylactic effect of resveratrol against Ethinylestradiol-Induced Liver Cholestasis. J Med Food. 2013;16(3):246-54

12. Zhi Z, Matthias F, Mark L, Robert S, Liu Y, Henrik L, et al. Polyphenols from 
Camellia sinenesis attenuate experimental cholestasis-induced liver fibrosis in rats. Am J Physiol Gastrointest. 2003;285(5):G1004-13.

13. Guerrero RF, García-Parrilla MC, Puertas B, Cantos-Villar, E. Wine, resveratrol and health: A review. Nat Prod Commun. 2009;4(5):635-8.

14. Baur JA, Sinclair DA. Therapeutic potential of resveratrol: The in vivo evidence. Nat Rev Drug Discov, . 2006;5(6):493-506.

15. Hussein MA. A convenient mechanism for the free radical scavenging activity of resveratrol. Int J Phytomed. 2011;3(4):459-69.

16. Majid M, Fatemeh $H$, Mohamad R. Comparison of effect of resveratrol and vanadium on diabetes related dyslipidemia and hyperglycemia in streptozotocin induced diabetic rats. Adv Pharmaceut Bull. 2011;2(1):81-6.

17. Kreuter J. Nanoparticles-a historical perspective. Int J Pharm. 2007;331(1):1-10.

18. DeJong $W H$, Borm PJ. Drug delivery and nanoparticles: Applications and hazards. Int J Nanomedicine. 2008;3(2):133-49.

19. Cho K, Wang X, Nie S, Chen ZG, Shin DM. Therapeutic nanoparticles for drug delivery in cancer. Clin Cancer Res. 2008;14(5):1310-6.

20. Ibrahim WM, AlOmrani AH, Yassin AE. Novel sulpiride-loaded solid lipid nanoparticles with enhanced intestinal permeability. Int J Nanomedicine. 2014;9:129-44

21. Hussein MA, Kasser AK, Mohamed AT, Eraqy TH, Asaad A. Resveratrol nanoemulsion; a promising protector against Ethinylestradiol-induced Hepatic Cholestasis in Female Rats. J Biomol Res Ther. 2019;8(175):2.

22. Shanmugavelu M, Adluri RS, Venugopal P, Namasivayam N. Protective effect of quercetin on nicotine-induced prooxidant and antioxidant imbalance and DNA damage in Wistar rats. Toxicology. 2008;243(1-2):207-15.

23. Fossati P, Prencipe L. Serum triacylglycerols determined calorimetrically with an enzyme that produces hydrogen peroxide. Clin Chem. 1982;1:2077-80.

24. Allain CC, Poon LS, Chan CS, Richmond W, Fu PC. Enzymatic determination of total serum cholesterol. Clin Chem. 1974;20(4):470-5.

25. Burnstein M, Selvenick HR, Morfin R. Rapid method for isolation of lipoprotein from human serum with polyanions. J Lipid Res. 1970;11(6):583-95.

26. Falholt K, Falholt W, Lund B. An easy colorimetric method for routine determination of free fatty acids in plasma. Clin Chim Acta. 1973;46(2):105-11.

27. Suttle N. Copper deficiency in ruminants: Recent developments. Vet Rec. 1986;119(21):519-22

28. Paglia D, Valentine W. Studies on the quantitative and qualitative characterization of erythrocyte glutathione peroxidase. J Lab Clin Med. 1967;70(1):158-69.

29. Esterbauer $H$, Schaure R, Zollner H. Chemistry and biochemistry of 4-hydroxynonenal malonaldehyde and related aldehydes. Free Radic Biol Med.
$1991 ; 11(1): 81-128$

30. Bancroft GD, Steven A. Theory and Practice of Histological Technique, $4^{\text {th }}$ ed. Churchill Livingstone, New York. 1983;99-112.

31. George $P$, Anastasia M, Spyridon P, Efthimia Z. Effects of Smoking on Cardiovascular Function: The Role of Nicotine and Carbon Monoxide. Health Science Journal. 2014;8(2):275-90.

32. Gepner AD, Piper ME, Johnson HM, Fiore MC, Baker TB, Stein JH. Effects of smoking and smoking cessation on lipids and lipoproteins: Outcomes from a randomized clinical trial. Am Heart J. 2011;161(1):145-51.

33. Schaffer JE. Lipotoxicity: When tissues overeat. Cur Opin Lipidol. 2003;14(3):281-7.

34. Kawamura K, Kobayashi Y, Kageyama F, Kawasaki T, Nagasawa M, Toyokuni S, et al. Enhanced hepatic lipid peroxidation in patients with primary biliary cirrhosis. Am J Gastroenterol. 2000;95(12):3596-601.

35. Aggarwal B, Shishodia S, Sandur S, Pandey M, Sethi G. Inflammation and cancer: How hot is the link?. Biochem Pharmacol. 2007;72(11):1605-21.

36. Kundu J, Surh Y. Molecular basis of chemoprevention by resveratrol: NF-kappaB and AP-1 as potential targets. Mutat Res. 2004;555(1-2):65-80

37. Strater J, Moller P. Pathogenesis of primary biliary cirrhosis: CD 95-induced apoptosis at last. Eur J Gastroenterol Hepatol. 1998;10(7):553-7.

38. Leonard S, Xia C, Jiang B, Stinefelt B. Resveratrol scavenges reactive oxygen species and effects radical-induced cellular responses. Biochem Biophys Res Commu. 2003;309(4):1017-26.

39. Das B, Sarkar C. Is preconditioning by oxytocin administration mediated by iNOS and/or mitochondrial K(ATP) channel activation in the in vivo anesthetized rabbit heart? Life Sci. 2012;90(19-20):763-9.

40. Csiszar A, Smith K, Labinskyy N, Orosz Z, Rivera A, Ungvari Z. Resveratrol attenuates TNF-alpha-induced activation of coronary arterial endothelial cells: Role of NF-kappaB inhibition. Am J Physiol Heart Circ Physiol. 2006;291(4):H1694-9.

41. Ungvari Z, Orosz Z, Rivera A, Labinskyy N, Xiangmin Z, Olson S, et al Resveratrol increases vascular oxidative stress resistance. Am J Physiol Heart Circ Physiol. 2007;292(5):H2417-24.

42. Labinskyy N, Csiszar A, Orosz Z, Smith K, Rivera A, Buffenstein R, et al Comparison of endothelial function, $\mathrm{O}_{2}$-and $\mathrm{H}_{2} \mathrm{O}_{2}$ production and vascular oxidative stress resistance between the longest-living rodent, the naked mole rat and mice. Am J Physiol Heart Circ Physiol. 2006;291(6):H2698-704.

43. Usta E, Mustafi M, Walker T, Ziemer G. Resveratrol suppresses apoptosis in intact human cardiac tissue - in vitro model simulating extracorporeal circulation. The Journal of Cardiovascular Surgery. 2011;52(3):399-409.
GRAPHICAL ABSTRACT

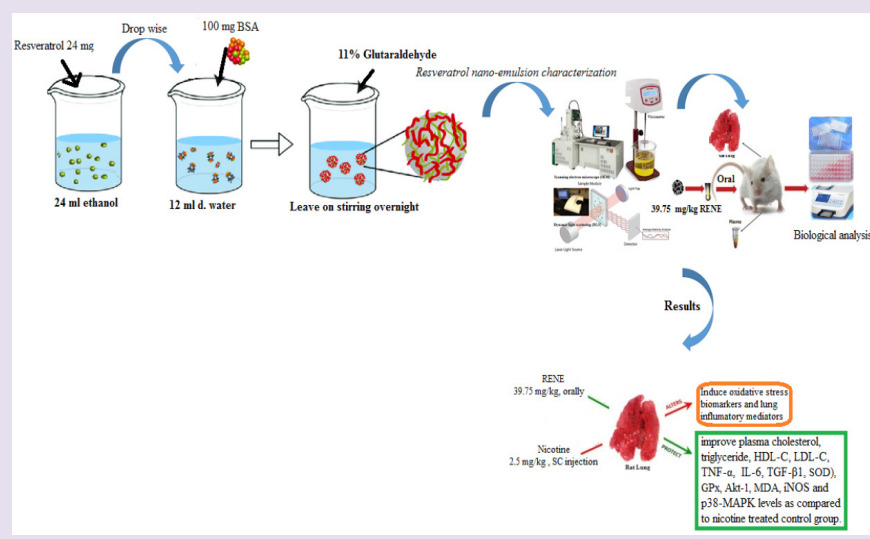

\section{SUMMARY}

In the present study, RENE was prepared, characterized and evaluated for its lung protective activity against nicotineinduced lung toxicity using the following biochemical molecular parameters; cholesterol, triglyceride, HDL-C, LDL-C, TNF- $\alpha$, IL-6, TGF- $\beta 1$, SOD, GPx, Akt-1, iNOS and p38-MAPK. The obtained biochemical, molecular biology and histological results of our study proved the lung protective activity of RENE against nicotine induced lung toxicity in rats. 


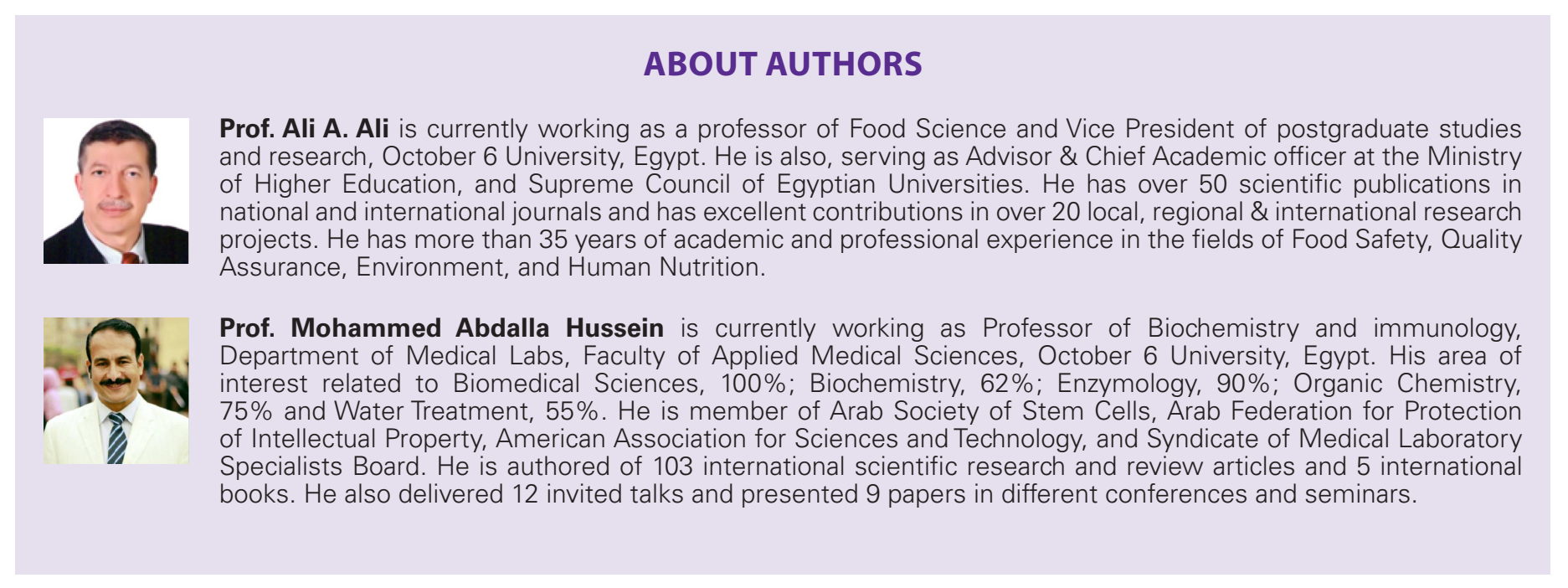

Cite this article: Mohamed FT, Abdelghfour AY, Morsy BA, Rizk DD, Elwany RM, Samir SA, Ali AA, Hussein MA. Resveratrol Nanoemulsion; A Promising Inhibitor against Mitogen-Activated Protein Kinase - Dependent Inflammation and Ameliorates Nicotine induced-lung Toxicity in Rats. Free Radicals and Antioxidants. 2020;10(1):35-41. 